\title{
Brexit's Challenge to Globalization and Implications for Asia: A Chinese Perspective
}

\author{
Shucheng Wang*
}

Brexit represents a backlash against globalization and runs in parallel with Donald Trump's presidential election. Both of these signal the rise of the nation-state and the rejection of the neoliberal vision of globalization in which national sovereignty has been increasingly dissolved. The article argues that it also has fundamental implications for Asia. In particular, China as the world's second largest economy is playing a bigger role in the region. Furthermore, with the rise of China, Asia's global order has become relatively fragile and multilayered in the sense that all big powers, such as the US and Japan, have their relative positions in the region simultaneously. In this regard, it would be more realistic for Asian countries to base their integration on their national sovereignty in a pragmatic way that they can maintain flexibility to the changing order of the world.

\section{Keywords}

Brexit, Globalization, Asia, Rise of China, National Sovereignty

* Professor/Visiting Fellow at the City University of Hong Kong School of Law; Chutian Scholar Professorship at Zhongnan University of Economics and Law, China. LL.M. (Oxon), Diploma (Emory), Ph.D. (Renmin Univ.) ORCID: http://orcid.org/0000-0001-6093-0574. The author may be contacted at: shucheng.wang@fulbrightmail.org / Address: City University of Hong Kong School of Law, Tat Chee Avenue, Kowloon, Hong Kong. DOI: http://dx.doi.org/10.14330/jeail.2017.10.1.03 


\section{Introduction}

Since the end of World War II, Europe has witnessed the creation of a single market. This began in the 1950s with the Treaty of Rome and accelerated in the late 1980s and the early 1990s with the 1992 Maastricht Treaty and the Single Market Act that came into force in 1993. This set out the ideas of free movement of capital, people and goods, trickle-down economics, a much diminished role for nation states, and the importance of market forces. ${ }^{1}$ As a consequence, the integration process was accelerated at an unprecedented pace, bringing rapid internationalization of the market economy with it. This aimed to improve the EU's competitiveness with North America and the Far East. Its proponents have argued that only a market of continental dimensions can provide the security and the economies of scale needed for the survival of the European capital, i.e. of Europe-based multinationals. ${ }^{2}$ After the collapse of the Soviet bloc, nobody would challenge capitalism as a system, nor would the merits of globalization in the context of Europe. Hutton sets out the vision of globalization in the EU in the following terms:

The countries of the EU together have the power to regulate the financial markets and control capital flows, and to play a part in compelling the US and Japan to regulate their relationship better, as part of a world deal ... Europe can insist on common social rights across the continent so that multinational corporations cannot play one state off against another in an effort to bid down wages and working conditions. Europe can set common environmental standards and common rules of corporate governance, establishing the concept of the stakeholder company. Indeed, social market Europe can formalize its rules and codes so that ... a co-operative, more committed form of capitalism could be defended. ${ }^{3}$

This neoliberal trend prevailed until the victims of globalization stood up against it. In December 1999, the violent protest in Seattle during the World Trade Organization ("WTO")'s ministerial meeting signaled that not everyone saw the move towards such a neoliberal form of globalization as positive. The trend of anti-globalization,

1 L. Elliot, Brexit is a Rejection of Globalization, GUARDIAN, June 26, 2016, available at https://www.theguardian. com/business/2016/jun/26/brexit-is-the-rejection-of-globalisation (last visited on Jan. 10, 2017).

2 T. Fotopoulos, Brexit, Globalization and the Bankruptcy of the Globalist "Left," GLoBAL Res., June 25, 2016, available at http://www.globalresearch.ca/brexit-globalization-and-the-bankruptcy-of-the-globalist-left/5519403 (last visited on Jan. 22, 2017).

3 W. Hutton, The State We're In 315-6 (1995).

4 Elliot, supra note 1. 
of which Brexit is one example, is taking place in both peripheral and core Eurozone countries, as well as across the Atlantic where Donald Trump has won the support of people who are complaining of job losses, influx of foreigners and loss of market share because of free trade. ${ }^{5}$ Furthermore, the EU's experience over the last two decades has been exactly the opposite. Following the higher integration achieved within the EU in the 1990s, the EU's competitiveness has been lagging behind that of the US. ${ }^{6}$

Admittedly, globalization in itself is clearly good for the purposes of 'levelingup' and reducing poverty. According to the World Bank, the share of the global population "living on less than USD 1.25 per day fell from 36 percent in 1990 to 18 percent in 2010 - projected to further fall to 9 percent in 2020."7 Batten agrees with these figures, stating that: "Globalization has produced the greatest expansion in wealth worldwide in history and the biggest beneficiaries have been the poor in developing countries. Of course, the rich in poor countries benefit most of all but nevertheless wealth filters down. The BRICS (i.e. Brazil, Russia, India, China and South Africa), and most particularly China, have benefited the most."

However, globalization has been facing challenges in terms of global wealth distribution. A survey shows that in the 20-year period 1988-2008, wealth in the world increased as follows: incomes of BRICS countries increased by 76 percent; for the super-rich, the 1 percent, it increased by 70 percent; for the ordinary rich in developed countries, up by 26 percent; for the upper middle class in developed nations, up by 16 percent; for the "wretched of the earth" it went up by 12 percent; for the lower middle class in developed countries, up by 5 percent; for working class in developed nations, up by 3 percent; and for working poor in developed nations, up by 1 percent. ${ }^{9}$ Clearly, a very small group of people, the top 1 percent in developed countries who already own most of the world's wealth, have benefited extraordinarily from globalization. As far as Brexit is concerned, after analyzing the voting patterns in the referendum, it was found that "those parts of Britain with the strongest support for Brexit were those

5 N. Chandran, How Brexit Impacts Globalization, CNBC, June 28, 2016, available at http://www.cnbc.com/2016/06/28/ how-brexit-impacts-globalization.html (last visited on Jan. 25, 2017).

6 European competitiveness has fallen by 3.7 percent since 1980, while the US competitiveness has risen by 2.2 percent and Japanese competitiveness (which for many years has been on top of the competitiveness league) increased by 0.5 percent. See T. Fotopoulos, Towards an Inclusive Democracy 62-109 (1997).

7 F. Paasschen, Globalization from a Business Leader's Point of View, 22 Brown J. World Aff. 178 (2015).

8 A. Batten, Globalization: Is Brexit the Tipping Point, Asia Sentinel, July 6, 2016, available at http://www.asiasentinel. com/blog/globalisation-brexit-tipping-point (last visited on Jan. 8, 2017).

9 Oxfam tells us that now just 62 billionaires own more wealth than the bottom half of the world's population. See id. 
that had been poor for a long time." ${ }^{, 10}$ Furthermore, the British public has realized that its national and economic sovereignty has been decisively impinged on by the EU. ${ }^{11}$ This means that Britain, like other EU members, can hardly be called economically sovereign as it is largely manipulated by the bureaucrats controlling the European Central Bank, and furthermore, about 50 percent of UK legislation with significant economic impact originates from EU legislation. ${ }^{12}$ As Fotopoulos states: "Greece and Cyprus are examples to show that the Eurozone elites can at any moment financially strangle any members that do not obey their instructions by simply turning off the liquidity tap."13

Against this background, the issue to be addressed is the extent to which a nationstate should try to adapt to the changing landscape of globalization in a post-Brexit era, given the high interdependence of countries after decades of global integration. Specifically, this paper is composed of two parts. The first will examine the ways in which globalization has resulted in the decline of nation-states. Within this, an attempt will be made to explore the impact of Brexit on globalization, and to address the appropriate role of a nation-state in the process of globalization in a post-Brexit era. The second part will discuss the implications that Brexit has for Asia, given the rise of Asia, which contains extraordinary diversity, and in particular, that of China which is increasingly exerting influence over the region.

\section{Brexit's Challenge to Globalization}

\section{A. Globalization and the Decline of Nation-States}

At present, globalization seems to be a conflation of 'everything' that has a pervasive feature. Advanced digital technology and communications have made it possible for businesses to extend their reach across borders, benefiting from lower labor costs, cheaper natural resources, greater production scale and new markets. In doing this, a large number of products, services and supply chains now cut across

\footnotetext{
10 Elliot, supra note 1.

11 P. Foster, What would Brexit mean for British sovereignty?, Telegraph, June 8, 2016, available at http://www. telegraph.co.uk/news/2016/05/19/how-does-the-eu-impinge-on-british-sovereignty-and-if-the-uk-vot (last visited on Mar. 26, 2017).

12 Id.

13 Fotopoulos, supra note 2.
} 
borders. ${ }^{14}$ It is always challenging to theorize about globalization which is extremely multidimensional. ${ }^{15}$ At its inception, globalization was perceived as "an economic phenomenon of increased cross-border movements of goods, people, and capital." From the 1990s onwards, it became a buzzword in various scholarly fields. In the 1970s and 1980s, it was depicted as an "intensified phase of interdependence ... that transcends states' exclusive authority and control."16 Such a conceptual trajectory shows that globalization has diminished sovereign nations.

The primary goal of the Maastricht Treaty was to improve competitiveness through a neoliberal approach, followed by the mechanisms established by the Economic and Monetary Union (1999-2002) and the Eurozone. However, both "signified not the integration of peoples, or even the integration of States, but just the integration of free markets."17 Moreover, the task of the Maastricht Treaty was mainly to eliminate the 'institutional' barriers to free competition. ${ }^{18}$ Therefore, the neoliberal consensus was largely formulated for renewing the EU's institutional framework, under which it could further "maximize the freedom of organized capital and minimize the freedom of organized labor through any means available and, particularly, through the threat of unemployment."19

Free market does not just mean the unimpeded movement of commodities, capital and labor, but also 'flexibility,' i.e., the elimination of barriers to the free formation of prices and wages, as well as the overall curtailing of the state's control over economic activity. ${ }^{20}$ In this neoliberal model, "the continuation of growth depended on a process of further internationalizing its economy, through the destruction of local economic self-reliance and the continual expansion of exports to cope with a growing volume of imports." ${ }^{21}$

The institutions of this model, such as the European Central Bank, European

14 Paasschen, supra note 7, at 165-76.

15 As noted, it is a much more encompassing and complex phenomenon than international relations. Accordingly, it is also much more ambiguous, less precise, and, to some extent, even incoherent. Some scholarly literature in both international relations and political science generally focuses on the concept of 'global politics' as denoting globalization of the contemporary political sphere rather than on globalization itself. See A. Kacowicz \& M. Mitrani, Why Don't We Have Coherent Theories of International Relations about Globalization?, 22 GLobal Governance 193 (2016).

16 Id. at 192.

17 Fotopoulos, supra note 2.

18 Id.

19 Id.

20 For details, see M. Schwarzschild, Free Trade then and Now, or Still Manchester United, 52 SAN DIEGO L. Rev. 106775 (2015).

21 Fotopoulos, supra note 2. 
Parliament and European Investment Bank etc., were almost taken for granted, while the issue of sovereign nations was largely ignored in the order, as mentioned above. It has even been depicted as a kind of globalist 'Left' whose goal is to build up the New World Order of neoliberal globalization, implying the phasing out of national sovereignty, in comparison with those of the nineteenth and early twentieth centuries based on nation-states. ${ }^{22}$ As a consequence, more small businesses disappeared from the high street and transnational corporations became the big winners. This meant that the butcher, the baker and the greengrocer selling local produce could no longer compete with the big players. ${ }^{23}$ Furthermore, some industries have become almost unviable as Member States are not allowed to prop up or subsidize uncompetitive businesses due to Europe's strict rules on state aid. ${ }^{24}$ In the case of steel, e.g., if Britain had been a sovereign nation it could have imposed tariffs to protect the industry from cheaper imported steel from countries like China. ${ }^{25}$

In fact, it has become more difficult for the countries within the Eurozone to implement different economic policies from those imposed by the Euro-elites. It has been observed that for the UK, which is actually much less dependent on the EU than most other Member States, "64.7 percent of the laws introduced in the UK since 1993 either originated from the EU or are deemed to be EU influenced." ${ }^{26}$ A country with such little economic sovereignty can hardly enjoy its national sovereignty; it would be otherwise "setting aside the disorienting distinction between power and sovereignty that Eurofans make." 27 In this sense, the nation-states have only a formal existence, given that their national sovereignty has been systematically dismantled within the EU. $^{28}$

Having said this, it seems that there exists a paradox between neoliberal globalization and the self-reliance of nation-states in Europe. On the one hand, "the minimization of the state's social role and of national sovereignty in general does

22 New World Order normally refers to the emergence of a totalitarian world government which replaces sovereign nationstates. See id.

23 T. Bancroft-Hinchey, UK-EU: In or Out? There is no “no," Pravda Report, Feb. 19, 2016, available at http:// www.pravdareport.com/opinion/columnists/19-02-2016/133529-eu_uk-0 (last visited on Jan. 10, 2017).

24 J. Collingridge, Sunset on Steel: Is There any Hope for Tata's Workers, Sunday Times, Apr. 3, 2016, available at http:// www.thetimes.co.uk/article/sunset-on-steel-f8rjwcnxn (last visited on Feb. 1, 2017).

25 Fotopoulos, supra note 2.

26 Definitive Study Reveals EU Rules Account for 65\% of UK Law, Bus. For BrITAIN, Mar. 2, 2015, available at http:// forbritain.org/bfbeta/2015/03/02/definitive-study-reveals-eu-rules-account-for-65-of-uk-law-2 (last visited on Jan. 16, 2017).

27 Y. Varoufakis, Why We Must Save the EU, GuARDian, Apr. 5, 2016, available at https://www.theguardian.com/ world/2016/apr/05/yanis-varoufakis-why-we-must-save-the-eu (last visited on Jan. 22, 2017).

28 Fotopoulos, supra note 2. 
not constitute a choice but a precondition for European capital (i.e. the Europe-based multinationals) to effectively compete with those based in the US or the Far East."29 On the other hand, any attempt to "change the present institutional framework, in order to radically enhance the state's social role, or to expand national sovereignty, allowing states to impose more social controls on markets than those based in the Far East or the US, would simply make European multinationals less competitive than those based in the rest of the world and would result in a mass exodus of European capital. ${ }^{, 30}$ It is clear that determining the appropriate position for nation-states will be a challenging issue that needs to be addressed in the post-Brexit era in Europe.

\section{B. Globalization in a Post-Brexit Era}

\section{Economic Interdependence and Integration of Nation-States}

After Brexit, it seems unrealistic to keep the idea that a more integrated Europe would collectively serve as the bulwark that nation-states can no longer provide, thereby moving on from a single market to a single currency, a single banking system, a single budget and eventually a single political entity. ${ }^{31}$ This is not to say that globalization will come to an end. The issue to be addressed is rather what form it should take moving forward. Even in the post-Brexit era, there is no doubt that countries can still benefit from their business activity across borders and from the global workflows. E.g., Nike was originally set up to import footwear made in Japan for American consumers. By 2015, however, markets outside North America accounted for 56 percent of Nike's revenues. ${ }^{32}$ A Nike shoe imported into Europe may have been designed in the US on Korean hardware for production at a Chinese factory. ${ }^{33}$ Even with the rise of nationalism, it is still generally believed that free trade is a main source of economic growth. This can be implied at least by the fact that, despite the US withdrawal from the Trans-Pacific Partnership ("TPP"), owing to its value as a free trade agreement, its members are still trying to save it. This may encourage China and other Asian nations to join and reformulate it. ${ }^{34}$ In this regard,

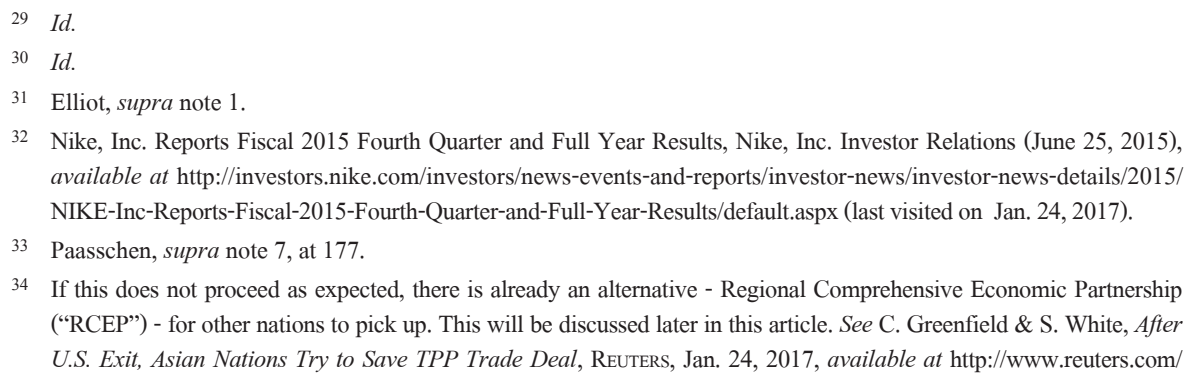

34 If this does not proceed as expected, there is already an alternative - Regional Comprehensive Economic Partnership ("RCEP") - for other nations to pick up. This will be discussed later in this article. See C. Greenfield \& S. White, After U.S. Exit, Asian Nations Try to Save TPP Trade Deal, Reuters, Jan. 24, 2017, available at http://www.reuters.com/ 
economic interdependence is still indispensable for overall economic growth in a time when the internet and digital technology have significantly reduced the cost of global communications and accelerated global integration. ${ }^{35}$ In this globalized world, retreat from the global market is more likely to provide more opportunities to other leading countries, such as China. Not surprisingly, after Donald Trump pledged to put 'America first,' a Chinese diplomat even suggested that China would be 'forced' to assume a global leadership role as the second-largest economy, as more countries start to rely on it for economic growth. ${ }^{36}$

Although Brexit might, in part, allow Britain to be independent from the rest of the EU politically (no matter whether the EU proceeds to a more integrated political union), given the indispensable economic interdependence of countries in this globalized world, the UK would not be able to break with the EU completely. Instead, it would clearly wish to maintain the "freest possible trade" with it. ${ }^{37}$ No matter what form this might take, it is less likely to bring about a fundamental change in the entrenched globalized economy in the short run, even if there is some partial adjustment. ${ }^{38}$ Of course, as long as a country is integrated into the global order, to a certain extent, it may inevitably subject to the regulations stipulated and implemented through the transnational institutions it has set up, such as the WTO, the IMF and the World Bank. ${ }^{39}$ Undoubtedly, "there is no simple zero-sum game between globalization and a country's free economic system, and they can coexist simultaneously." " Nonetheless, in a post-Brexit era, the UK will try to strike a balance between its integration with the EU at the regional level and its self-reliance based on national sovereignty at the domestic level. In the end, the UK will be able to do its own trade deals without needing to follow the same standards imposed by the EU. It will also be able to maintain migration at a 'sustainable' level. ${ }^{41}$

article/us-usa-trump-asia-idUSKBN15800V (last visited on Jan. 26, 2017).

35 Statistics shows that Internet users amounted to over three billion people - more than 40 percent of the world's population - as of 2015. See J. Davidson, Here's How Many Internet Users There Are, Tıme, May 26, 2015, available at $\mathrm{http} / / /$ ime.com/money/3896219/internet-users-worldwide (last visited on Jan. 26, 2017).

36 See Diplomat says China would Assume World Leadership if Needed, Reuters, Jan. 23, 2017, available at http:// uk.reuters.com/article/uk-china-usa-politics-idUKKBN1570YW (last visited on Jan. 25, 2017).

37 See Brexit: UK to Leave Single Market, Says Theresa May, BBC News, Jan. 17, 2017, available at http://www.bbc. com/news/uk-politics-38641208 (last visited on Jan. 18, 2017).

38 E.g., at present, Canadian multinationals decide how many aerospace jobs there will be in Northern Ireland and Indian entrepreneurs preside over the survival of the UK's steel industry. These same Indian entrepreneurs and their German and Japanese counterparts will decide the long-term health of British automotive manufacturing. See Fotopoulos, supra note 2 .

39 Id.

40 Kacowicz \& Mitrani, supra note 15, at 195.

41 PM May said she would remain committed to getting net migration down, which was defined as being below 100,000 


\section{Strengthening of Nation-States}

Despite the inevitable economic integration and interdependence of countries in the world order, Brexit demonstrates the indispensable role of the nation-state. This unexpected event denies the traditional premise that the process of globalization has rendered state-centric models completely obsolete in the contemporary world. ${ }^{42}$ Interestingly, a historical comparison showed that "jobs, living standards and welfare of the states were all better protected in the heyday of nation states in the 1950s and 1960s than they have been in the age of globalization." 43

Given the entrenched global integration, it is true that leaving Europe will not fully restore national sovereignty. E.g., the UK's energy security might still be dependent on the French and Chinese governments deciding whether or not Hinkley Point $\mathrm{C}$ is built. ${ }^{44}$ However, Brexit has clearly shown that strengthening the nation-state for the purpose of political and economic independence in the era of globalization is a necessary, though not sufficient condition for addressing the issues thereof. The huge resentment among Europeans against uncontrolled immigration is of course an indication of the effectively undermining national sovereignty. A recent poll showed that more Europeans want "Schengen to be halted and the reestablishment of border controls between neighboring countries: of which 72 percent of French want their borders sealed, while 66 percent of Germans and 60 percent of Italians want the same for their own countries. ${ }^{" 45}$ Considering that sovereignty has been fundamentally dismantled within the EU's framework of neoliberal globalization, strengthening nation-states is indeed a precondition to cope with the problems that are found within it.

Some experts are correct in stating that "globalization is more than a set of profound changes in capital and trade flows, rather manifests a substantial change in the way that we attempt to explain and make sense of the world." ${ }^{46}$ In this regard, a

a year by herself. It is currently running at 330,000 a year, of which 184,000 are the EU citizens. See A. Hunt \& B. Wheeler, Brexit: All You Need to Know about the UK Leaving the EU, BBC NEws, Jan. 24, 2017, available at http:/ www.bbc.com/news/uk-politics-32810887 (last visited on Jan. 26, 2017).

42 Kacowicz \& Mitrani, supra note 15, at 199.

43 Furthermore, "unemployment across the Eurozone is more than $10 \%$. Italy's economy is barely any bigger now than it was when the euro was created. Greece's economy has shrunk by almost a third. Austerity has eroded welfare provision. Labour market protections have been stripped away." See Elliot, supra note 1.

44 G. Ruddick, China Plans Central Role in UK Nuclear Industry after Hinkley Point Approval, Guardian, Sept. 15, 2016, available at https://www.theguardian.com/business/2016/sep/15/hinkley-point-chinese-firm-to-submit-essexnuclear-plant-plans (last visited on Jan. 20, 2017).

45 See French, Germans \& Italians Overwhelmingly in favor of Abandoning Border-free Europe - Poll, RT News, Apr. 7, 2016, available at https:/www.rt.com/news/338837-europeans-want-border-control (last visited on Jan. 20, 2017).

46 Kacowicz \& Mitrani, supra note 15, at 192. 
sovereign state needs to adopt a new mindset that encompasses new and unfamiliar conditions of globalization. This will enable nation-states not only to survive against all the odds and reinvent themselves in the face of this perhaps ontological change but also to respond by adopting and adapting to new roles to cope with the globalization through mechanisms of global and regional governance. ${ }^{47}$ In this sense, it is also necessary to strengthen national sovereignty in a way that each sovereign state is able to maintain its adaptability, which is impossible to achieve in the framework of the EU, for the changing world order.

Therefore, Brexit somehow reconfirms the argument that "the state is ... the key political unit in the international system" and "as long as the international system is divided into states the relations between states will have the characteristic of being about power politics." ${ }^{48}$ It is conceivable that, in a globalized world order, two dimensions of sovereign states, i.e., domestic and international, and territorial and non-territorial, may be dynamic and mixed. This may create overlapping networks of powers that cut across territorial boundaries. This aspect of power dimension also differs from the traditional Westphalian model of world order which is primarily based on the territorial sovereignty principle of the nation-state. This is surely not to deny the significant role of non-state actors in this globalized world order. ${ }^{49}$

\section{Brexit and the Rise of China: A Challenge to Globalization in Asia}

\section{A. Rise of China and a Changing Global Order in Asia}

Prior to World War II, international trade was dominated by colonial exploitation mainly under the hegemony of the British and French Empires. In the postwar era, however, the trade system changed and the US became hegemonic, both economically and militarily. At one point, the US accounted for over 50 percent of global GDP. ${ }^{50}$ To some extent, owing to the geopolitics of the Cold War era, the American trade policies were shaped to bring allies together and secure more strategic natural resources, such as its Marshall Plan which tied Europe to the US through international trade. At the

47 Id.

48 B. Buzan, D. Held \& A. McGrew, Realism versus Cosmopolitanism, 24 Rev. Int’L Stud. 387-8 (1998).

49 M. Naim, The End of Power: From Boardrooms to Battlefields and Churches to States, Why Being in Charge Isn't What It Used to Be (2014), re-cited from Kacowicz \& Mitrani, supra note 15, at 193.

50 F. Zakaria, The Post-American World 231 (2008). 
same time, the US supported the export-driven model for Japanese reconstruction. ${ }^{51}$

World War II resulted in a new world order and catalyzed the movements of national independence in Asia, which ultimately led to the retreat of colonial powers and the establishment of a number of nation-states in the region. During the second half of the twentieth century, Asia experienced a substantial increase in real GDP and significant structural change. Although some economies such like Japan, Hong Kong, South Korea, Singapore, Taiwan and China underwent great transformation, the majority are undergoing economic transformation slowly. ${ }^{52}$ With the slower globalization in Europe after Brexit, ${ }^{53}$ as well as across America during the presidency of Donald Trump (which can be implied from his anti-globalization policy, such as withdrawing from the TPP), Asian economies are likely to rely more on China's economy. ${ }^{54}$ At the same time, China's remarkable economic growth over the last quarter century will naturally lead it to play a bigger role in the region and across the world.

China has indeed been seeking to play a bigger role within and beyond the region. The "One Belt, One Road" (“OBOR") initiative, promoted by President Xi Jinping in 2013, e.g., is expected to increase the trade flows and infrastructure development particularly in Asia. This will exert a substantial influence over the existing model of trade integration in Asia. Today, some parts are relatively advanced, such as the Association of Southeast Asian Nations ("ASEAN") which operates as a free trade area with the establishment of the ASEAN Economic Community ("AEC") at the end of 2015, while other parts, such as South and Central Asia, are trailing behind with a slower pace of trade integration. ${ }^{55}$ Conceptually, "Belt refers to what was historically called the Silk Road, stretching from China through Central Asia. Road refers to a 'maritime road' which is to connect South East Asia with the Middle East, Europe and the east coast of Africa." ${ }^{56}$ In addition, in 2013, China proposed the Asian

51 Paasschen, supra note 7, at 185-6.

52 ADB, Asia's Economic Transformation: Where to, How, and How Fast? x (2013), available at https://www.adb.org/ sites/default/files/publication/30358/ki2013-special-chapter.pdf (last visited on Apr. 14, 2017).

53 A. Becker, Brexit - the End of Globalization?, Deutsche Welle, June 30, 2016, available at http://www.dw.com/en/ brexit-the-end-of-globalization/a-19369680 (last visited on Jan. 20, 2017).

54 Since China adopted the opening up policy in 1978, its GDP has grown rapidly. In 1978, foreign trade with China amounted to USD 20.6 billion and by 2005 that figure had risen to USD 851 billion. See Bijian Zheng, China's "Peaceful Rise" to Great-Power Status, 84 Foreign Aff. 18-9 (2005); E. Posner \& J. Yoo, International Law and the Rise of China, 7 CHI. J. INT'L L. 4 (2006).

55 P. Wolff, China's "Belt and Road" Initiative - Challenges and Opportunities, 2 German Development Institute Report (2016), available at https://www.die-gdi.de/uploads/media/Belt_and_Road_V1.pdf(last visited on Feb. 1, 2017).

56 Of course, any country that aspires to be part of the initiative is welcome to participate. At the same time, BRI can also help develop under-developed regions in China by connecting them to Central and South Asia. Eighteen western regions of China have been selected to participate in the initiative. See id. at 3. 
Infrastructure Investment Bank (“AIIB”) with 57 founding members to support the building of infrastructure in the Asia-Pacific region. ${ }^{57}$ It has gained strong support from 37 regional and 20 non-regional Prospective Founding Members ("PFM"), all of which have signed the Articles of Agreement that form the legal basis for the bank. ${ }^{58}$ Furthermore, China has been proposing another framework in Asia, i.e., the Regional Comprehensive Economic Partnership ("RCEP”), which is viewed as an alternative to the previous TPP trade agreement which excluded China and India. RCEP is a free trade agreement between the ten member states of the ASEAN (Brunei, Cambodia, Indonesia, Laos, Malaysia, Myanmar, the Philippines, Singapore, Thailand, Vietnam) and the six states with which the ASEAN has existing FTAs (Australia, China, India, Japan, South Korea and New Zealand). At present, the progress of RCEP depends on whether the TPP can be reformulated and can replace the RCEP by including China and other Asian economies in it. ${ }^{59}$ Clearly, all these show that China is playing a bigger role in the region and beyond.

At the same time, as more Asian countries are relying on China's economy, they may change their foreign policies towards China. A typical example is the Philippines, which under the new presidency of Rodrigo Duterte is casting aside Japan, its largest trade partner, pivoting away from the US as one of its closest allies in Asia, and building close ties with China. ${ }^{60}$ In particular, after the international arbitration ruling on the South China Sea which was actually in favor of the Philippines, Duterte unilaterally declared that the disputed Scarborough Shoal would become a fishing-free zone. This move seemingly aimed at further defusing its tensions with China, simply setting the arbitration aside and focusing on economic development issues first. ${ }^{61}$

57 The capital of the bank is USD100 billion, equivalent to $2 / 3$ of the capital of the Asian Development Bank and about half that of the World Bank. See Why China is Creating a New "World Bank" for Asia, Economist, Nov. 11, 2014, available at $\mathrm{http} / /$ www.economist.com/blogs/economist-explains/2014/11/economist-explains-6 (last visited on Jan. 25, 2017).

58 See Asian Infrastructure Investment Bank Articles of Agreement, available at http://www.mof.gov.cn/ zhengwuxinxi/caizhengxinwen/201506/P020150629360882722541.pdf (last visited on Jan. 10, 2017).

59 RCEP negotiations were formally launched in November 2012 at the ASEAN Summit in Cambodia. In 2016, RCEP population was 3.4 billion people, with a total GDP of USD 21.4 trillion (approximately 30 percent of global GDP). See S. Ribka \& L. Yulisman, RCEP Talks Speed up amid TPP Failure, JAKARTA Post, Dec. 7, 2016, available at http:// www.thejakartapost.com/news/2016/12/07/rcep-talks-speed-up-amid-tpp-failure.html (last visited on Jan. 5, 2017).

60 J. Perlez, In China, Rodrigo Duterte and Philippines May "Pivot” Away From U.S., N.Y. Tıмes, Oct. 18, 2016, available at http://cn.nytimes.com/asia-pacific/20161018/rodrigo-duterte-philippines-china-us/en-us.See also H. Beech, How Philippine President Rodrigo Duterte Is Shaking Up the South China Sea, TIME, Oct. 27, 2016, available at http:// time.com/4547711/philippines-rodrigo-duterte-south-china-sea (last visited on Jan. 26, 2017).

61 B. Bland, Duterte "Bans" all Fishing in Disputed Area of South China Sea, Fin. Times, Nov. 21, 2016, available at https://www.ft.com/content/d0ef9402-afd4-11 e6-9c37-5787335499a0 (last visited on Jan. 28, 2017). 
Even outside the region, more countries are turning to China for comprehensive cooperation. Recently, e.g., the African nation of Sao Tome and Principe re-established diplomatic ties with China. It has shifted its allegiance from Taiwan given its growing risk of isolation amid tensions with China, in the hope of securing more Chinese investment. ${ }^{62}$ European countries are also gradually building close ties with China. Taking Norway as an example. Its diplomatic relations with China were frozen after the Nobel Peace Prize was awarded to Chinese dissident Liu Xiaobo in 2010, but now it has attempted to and fully achieved normalization of political relations with China. ${ }^{63}$ In addition, more countries in Central, Eastern and Southern Europe have linked their economic fortunes to attracting Chinese investments into their infrastructure. ${ }^{64}$

Against this background in which power is shifting, the major countries with connections to Asia should reassess their status and re-prioritize global network. This means that existing great powers should yield peacefully to the rising powers and adapt themselves to the new situation appropriately. Otherwise, it is more likely to bring about confrontations which could lead to more serious conflicts and even war. ${ }^{65}$ Previously, the effectiveness of the WTO mainly depended on the political consensus among major players, including the EU, Japan and the US. With the rise of China, the triangle has become a square and, to some extent, the WTO will be able to avoid disruptions on the margins only if these four powers can continue to cooperate over trade. Otherwise, the WTO system may be rendered irrelevant and even replaced. ${ }^{66}$

In the same vein, the past dominant powers in Asia should amend their policy in proportion to their relative power, ensuring its consistency with the existing balance of power. E.g., the rise of China suggests that the US as a dominant power in Asia prepare to adjust its foreign policy therein and even renegotiate a host of important

62 See China Revives Ties with African Nation in Blow to Taiwan, Bloomberg, Dec. 26, 2016, available at https://www. bloomberg.com/politics/articles/2016-12-26/china-revives-diplomatic-ties-with-african-nation-in-taiwan-blow (last visited on Jan. 1, 2017).

63 The Norwegian Government reiterates its commitment to the one China policy, fully respects China's sovereignty and territorial integrity, and attaches high importance to China's core interests and major concerns. It will not support actions that undermine them, and will do its best avoiding any future damage to the bilateral relations. Moreover, it is reported that, immediately after the normalization, the shares of Norwegian salmon exporters, which had been largely excluded from the Chinese market due to reports that it was 'unhealthy,' rose on Monday, with Grieg Seafood and Marine Harvest up 2.7 and 1.6 percent, respectively. See L. Bos, Norway-China Relations “Unfrozen,” Diplomat, Dec. 21, 2016, available at http:/thediplomat.com/2016/12/norway-china-relations-unfrozen (last visited on Jan. 4, 2017).

64 J. Gaspers, Germany Wants Europe to Help Shape China's Belt and Road Initiative, Diplomat, Dec. 17, 2016, available at $\mathrm{http} / /$ thediplomat.com/2016/12/germany-wants-europe-to-help-shape-chinas-belt-and-road-initiative (last visited on Jan. 6, 2017).

65 Posner \& Yoo, supra note 54, at 8.

66 Id. at 14. 
multilateral treaties that powerful China is not willing to obey. For their part, the nation-states in the region should reshape their past paradigms of foreign relations, which may be driven by excessive national interests or antagonism, and make it more suited to the new paradigm. ${ }^{67}$ Otherwise, some international rules, which are now a mismatch with the existing balance of power, may be difficult to implement in reality because some larger states could refuse to obey them. ${ }^{68}$ During the Cold War, international law and institutions played limited role. In the Cuban missile crisis, e.g., even though America's blockade of Cuba certainly violated the UN Charter, there were no legal consequences. ${ }^{69}$ This has parallel implications with the current South China Sea case. China neither acknowledged nor accepted the verdict of the Permanent Court of Arbitration over strategic reefs and atolls that Beijing claims would give China control over the disputed waters of the South China Sea. ${ }^{70}$ Posner and Yoo predicted this a decade ago when they stated that "China, like all rising powers, will most likely seek to change the status quo, and this, as a practical matter, means breaking international law and asserting new international norms." ${ }^{, 71}$

Not surprisingly, such a change in Asia has presented a tremendous challenge to the international order in the region. Although it may be a process of constant friction to reconcile with each other, there is no doubt that the nation-states in the region must try hard to maintain their adaptability to the changing order. ${ }^{72}$

\section{B. Globalization and Regional Security in Asia: Reflecting Brexit}

It is true that globalization, as distinct from economic interdependence, transcends the mere economic realm because it affects all social arenas in different ways and magnitudes, and focuses on both processes and outcomes. ${ }^{73}$ Although globalization has entailed the economic interdependence and integration of different countries, history shows that this may not wholly prevent the outbreak of war. Prior to World War I, European countries enjoyed a level of economic interdependence. However, this kind of mutually beneficial economic relationship did not prevent the outbreak

67 Paasschen, supra note 7, at 186.

68 Posner \& Yoo, supra note 54, at 8-9.

69 In most cases, the International Court of Justice has involved disputes between relatively friendly States. In a few contentious cases between hostile States, however, the parties concerned would refuse to comply with its decisions. See id. at 6 .

70 See Beijing Rejects Tribunal's Ruling in South China Sea Case, Guardian, July 12, 2016, available at https://www. theguardian.com/world/2016/jul/12/philippines-wins-south-china-sea-case-against-china (last visited on Jan. 14, 2017).

71 Posner \& Yoo, supra note 54, at 10.

72 Kacowicz \& Mitrani, supra note 15, at 205.

$73 I d$. at 192. 
of a devastating war, despite predictions to the contrary. ${ }^{74}$

Nonetheless, there is no doubt that deepening economic integration can to some extent reduce the risk of confrontation or the like in the region. Although Brexit may force the EU to rethink its aims and methods, given Europe's bloody past and troubled present, helping to destroy the major vehicle for European cooperation will not be a good idea, for security reasons if nothing else. It would also be a serious mistake for the UK to undermine any relevant organization that is crucial to Britain's own security. ${ }^{75}$ In this sense, Brexit is not intended to lead to political isolation, nor to an exit from alliances such as NATO, either. At least, there is no sign of this at present. ${ }^{76}$ To some extent, due to shared common interests, participation in the NATO for security reasons is a kind of catalyst for its participation in the new world order. This has led "Britain into a series of wars in the last quarter of a century or so (Yugoslavia, Iraq, Afghanistan, Libya) for the sake of the Transnational Elite's interests and those of its members based in Britain." 77 In this regard, the "peace argument' can be made against Brexit. Green Party MP Caroline Lucas put it as follows:

Europe is not, historically, a very peaceful place. It would be sheer folly to think that armed conflict cannot return. We cannot know what dangers lie ahead. But we can be sure that a strong and stable European Union, with Britain as an active and positive participant, provides the surest guarantee of our national security. ${ }^{78}$

Furthermore, she states that "EU membership is Britain's best defence against the risk of Europe descending into war." ${ }^{, 79}$ Therefore, for security reasons, it is still significant for the UK to be part of the NATO, even if Brexit does have some side effects for the Alliance. ${ }^{80}$ Of course, the structure of the NATO may be subject to some adjustment

74 Posner \& Yoo, supra note 54, at 13. See also J. Mearsheimer, The Tragedy of Great Power Politics 370-2 (2001).

75 G. Rachman, Brexit is no Way Out of a Europe in Crisis, Fin. Times, Jan. 2, 2016, available at https://www.ft.com/ content/8ba35856-c8d1-11e5-be0b-b7ece4e953a0 (last visited on Jan. 5, 2017).

76 A. Rafferty, British PM Theresa May: U.K., U.S. “United in Our Recognition of NATO,” NBC News, Jan. 27, 2017, available at http://www.nbcnews.com/politics/politics-news/trump-welcomes-british-pm-theresa-may-first-foreignvisit-n713131 (last visited on Jan. 28, 2017).

77 Fotopoulos, supra note 2.

78 A. Asthana \& H. Stewart, EU Referendum: Rolls-Royce Warns its Staff of Brexit Risks, GuARDIAn, Mar. 2, 2016, available at https://www.theguardian.com/business/2016/mar/02/rolls-royce-tells-employees-britain-better-in-eu (last visited on Jan. 28, 2017).

79 Id.

80 See Russian Media Unhappy with NATO Summit, BBC News, July 8, 2016, available at http://www.bbc.com/news/ world-europe-36745994 (last visited on Jan. 17, 2017). 
in the future on the premise of recognizing its significance. This can be signaled by Trump's recent comment that the NATO, though still indispensable, was 'obsolete' in the sense that it was not taking care of terror and only five of its 28 members were paying their fair share. ${ }^{81}$

Given the high degree of economic interdependence between the transnational corporations based in these cooperating countries, wars between them are inconceivable today. ${ }^{82}$ This means that the common interests resulting from economic interdependence and integration within the blocs can simultaneously ease the potential tension and somehow preclude wars between them. In the context of Europe, "any military conflict between the states on which the Transnational Elite is based (mainly the G7 states and its associate in Scandinavia, Australia, etc.) is inconceivable today and any difference between them, like those that arose in connection to the Iraq war or Syria, were purely tactical and never reflected any antagonistic conflicts." ${ }^{\circ 3}$ Clearly, this kind of promoting effect for regional security would not mean the absolute impossibility of confrontation within the region. In addition, history shows that it was no more integrated in aggregate terms than it was in the latter part of the nineteenth century and the early years of the twentieth century. ${ }^{84}$

In the context of Asia, however, there are more inherent difficulties in creating a so-called "Concert of Asia" than the "Concert of Europe" because the latter, "modeled in the nineteenth century ... arose in the wake of the French Revolutionary and Napoleonic Wars." Such concert systems "survive for about as long as the existing hegemon is not under an emerging threat from a rising power." ${ }^{85}$ In theory, "as the memories of the war vanish and the threat recedes, the concert system weakens, tending to revert to a balance of power instead. And the ensuing balance of power is itself fragile, likely to be disrupted by another major war among the erstwhile concert members." ${ }^{\prime 66}$ In comparison, Asia neither has the conditions for a 'Concert,' nor a regional framework such as the African Union, the Organization of American

81 See Trump Worries NATO with "Obsolete" Comment, BBC News, Jan. 16, 2017, available at http://www.bbc.com/ news/world-us-canada-38635181 (last visited on Jan. 17, 2017).

82 Fotopoulos, supra note 2.

83 Id.

84 P. Bairoch, Globalization Myths and Realities: One Century of External Trade and Foreign Investment, in STATE against Market: The Limits of Globalization 173-92 (R. Boyer \& D. Drache eds., 1996). See also P. Hirst \& G. Thompson, Globalization in Question (2d ed. 1999); W. Lewis, The Rate of Growth of World Trade, 1830-1973, in The World Economic Order: Past and Prospects (S. Grassman \& E. Lundberg eds., 1981).

85 R. Delahunty, Towards a Concert of Asia? A Proposed International Security Regime, 11 U. PA. Asia L. Rev. 1 (2015).

86 Id. at 78 . 
States or the European Union. Overall, Asian countries have the lowest participation and representation in international law and institutions. ${ }^{87}$ The differences of culture, history and ideology between countries are partly the barriers for them to enter into "the general community of international law" within the region. ${ }^{88}$ In this regard, the diversity of the continent makes it more likely to be a fragile regional integration, and the countries in the region, in particular small economies, are more likely to have overlapping integration with different big powers like the US and China, simultaneously. This can be signaled by Singapore's recent clarification on its foreign policy that welcomes China's engagement in the region, while remaining a friend of the US even though these two partners have significantly different ideologies and strategic interests. ${ }^{89}$

Under these circumstances, for both economic and security reasons, big powers and economies in the region or outside with significant influence (such as the US, Japan, China and perhaps India) are more likely to make an effort to establish and strengthen ties with other Asian states. In particular, those who share similar ideologies may have a stronger need to cooperate in today's turbulent world. ${ }^{90}$ Japan remains outside the AIIB, presumably in order to preserve its strong ties with the US. This trend to some extent explains its privileged role in the Asian Development Bank in competition with the AIIB. ${ }^{91}$ At the same time, owing to the growing influence of China over the region, small Asian economies are more likely to deepen their economic relations with China. As discussed above, this kind of economic interplay with the major security providers can simultaneously advance their own security goals at lower costs and ease potential confrontations between them.

It is clear that the current integration of Asian countries is premised on their controllable sovereignty and the way that they can adapt their patterns of relations

87 For details, see S. Chesterman, Asia's Ambivalence about International Law \& Institutions: Past, Present, and Futures, 27 EuropeAn J. INT'L L. 946 (2017).

88 Within Asia, tensions have existed between Japan and China because the former successfully sought to be admitted into the company of the so-called 'civilized' in the nineteenth century - arguably at the expense of the latter. See J. Lai, Sovereignty and "Civilization": International Law and East Asia in the Nineteenth Century, 40 MODERN CHINA 282 (2014); Eric Y.J. Lee, Early Development of Modern International Law in East Asia - With Special Reference to China, Japan, and Korea, 4 J. His. Int’L L. 42 (2002); M. Koskenniemi, The Gentle Civilizer of Nations: the Rise AND Fall of INTERnational Law 1870-1960, 132-6 (2001); J. Pitts, Boundaries of Victorian International Law, in Victorian Visions of Global Order: Empire and International Relations in Nineteenth-Century Political Thought 75 (D. Bell ed., 2007).

89 Han Yong Hong, A New Chapter for Singapore-Sino Ties in the New Year, Straits Times, Jan. 31, 2017, available at http://www.straitstimes.com/opinion/a-new-chapter-for-singapore-sino-ties-in-the-new-year (last visited on Feb. 1, 2017).

90 Id.

91 Chesterman, supra note 87, at 972. 
and practices pragmatically to be both relevant and adequate to the new realities of Asia's global order, while maintaining the political differences between them. Indeed, the indispensable role of the nation-state, which is a lesson from Brexit, also has its reflections in the context of Asia.

\section{Conclusion}

Britain's vote to leave the EU represents a backlash against a globalized world. This suggests that nation-states will increasingly be restored. It is opposed to the previous neoliberal trend of globalization where sovereignty has been significantly dissolved. This does not mean the end of globalization, but instead a new era for the global integration of economies where nation-states will emerge as agents of change and transformation for the inevitable future economic interdependence, accompanied with the rise of nationalism.

In a globalized world, Brexit also has implications in the context of Asia. In particular, the rise of China has a growing influence on Asia's global order both economically and militarily. As a consequence, China has launched major initiatives, such as the OBOR and the AIIB, to engage in a more proactive way with the region. At the same time, Asian countries and even those outside have been relying more on China's economy. In this regard, the great powers, such as the US, Japan and potentially India, need to reassess their status and redistribute their power in a way that deepens economic integration, while alleviating potential confrontation and conflicts. In the same vein, geopolitically, other Asian countries need to reconfigure their economies to accord with the rise of China. This might also benefit security within the region. Against this background, strengthening national sovereignty is essential for maintaining the adaptability of the states in Asia's multilayered order with great powers of different ideologies therein. This ties in with Brexit which itself indicates the need for nation-states in a globalized world.

Given the diversity of Asia, which in part has resulted from its unique history, in particular concerning World War II and the Cold War, the global order of the continent is relatively fragile with overlapping influences from different big powers within and outside the region. Overall, with the rise of nationalism, it would be more realistic for Asian countries - in particular small economies - to take a pragmatic approach to the rise of China based on their national sovereignty, thereby coping with the changes and uncertainties in the world order. 